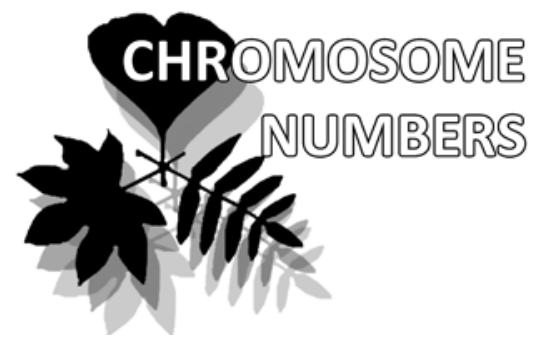

Nina S. Probatova ${ }^{1 *}$

e-mail:probatova@ibss.dvo.ru

Vitaly P. Seledets ${ }^{2}$

e-mail: probatova@ibss.dvo.ru

Olga A. Chernyagina ${ }^{3}$

e-mail:kamchatika@mail.ru

${ }^{1}$ Institute of Biology \& Soil Science FEB RAS, Vladivostok, Russia

${ }^{2}$ Pacific Institute of Geography FEB RAS, Vladivostok, Russia

${ }^{3}$ Kamchatka Branch of the Pacific Geographical Institute FEB RAS,

Petropavlovsk-Kamchatskii, Russia

* corresponding author

Manuscript received: 24.10 .2016

Review completed: 10.11.2016

Accepted for publication: 11.11.2016

Published online: 18.11.2016

\title{
Chromosome numbers in some species of Poaceae from Russia: further studies
}

\author{
Nina S. Probatova ${ }^{1 *}$, Vitaly P. Seledets ${ }^{2} \&$ Olga A. Chernyagina ${ }^{3}$
}

\begin{abstract}
A B S T R A C T
Chromosome numbers for 37 species in Poaceae from 24 genera (Achnatherum, Agrostis, Anisantha, Arctopoa, Arrhenatherum, Arundinella, Avenella, Bromopsis, Cinna, Cleistogenes, Deschampsia, Digitaria, Elymus, Eragrostis, Festuca, Glyceria, Hordeum, Koeleria, Melica, Ochlopoa, Poa, Puccinellia, Schedonorus, Schizachne) from Russia are presented. In Anisantha haussknechtii (Boiss.) Holub, Arctopoa reventa Prob., Bromopsis bargusinensis (Drobow) Tzvelev, Deschampsia bybridogena Tzvelev, Koeleria sibirensis (Domin) Tzvelev and Puccinellia bultenii Swallen the chromosome numbers were revealed for the first time. The new chromosome numbers were obtained for Bromopsis flexuosa and Echinochloa caudata. For some regions chromosome numbers were obtained first: for Cinna latifolia, Digitaria ischaemum and Echinochloa caudata - in Siberia, Achnatherum confusum - in West Siberia, Deschampsia susumanica and Eragrostis minor - in the Russian Far East, Avenella flexuosa - in the Kuril Islands, Agrostis scabra, Bromopsis ciliata, Elymus novae-angliae, Eragrostis multicaulis, Hordeum brachyantherum, $H$. jubatum, Ochlopoa annua, Poa angustifolia and P. trivialis - first in Kamchatka Peninsula, Bromopsis flexuosa was studied first in Khabarovskii Krai, Achnatherum splendens, Elymus peschkovae, Melica nutans and Schizachne callosa - in Irkutskaya Oblast', Cleistogenes squarrosa and Hordeum jubatum - in Buryatia Republic, Arundinella anomala - in Zabaikal'skii Krai, Poa attenuata - in Sakha (Yakutia) Republic.
\end{abstract}

Ke y w o r d s : chromosome numbers, vascular plants, Poaceae, flora, Russia

\section{P E 3 Ю M E}

Пробатова Н.С., Селедец В.П., Чернягина О.А. Числа хромосом некоторых видов змаков (Роасеае) России: Аальнейшее изучение. Сообщаются чис $а$ хромосом (2n) Аля 37 видов злаков из 24 родов (Achnatherum, Agrostis, Anisantha, Arctopoa, Arrhenatherum, Arundinella, Avenella, Bromopsis, Cinna, Cleistogenes, Deschampsia, Digitaria, Elymus, Eragrostis, Festuca, Glyceria, Hordeum, Koeleria, Melica, Ochlopoa, Poa, Puccinellia, Schedonorus, Schizachne) во фморе России. Впервые исслелованы в кариологическом отношении Anisantha baussknechtii (Boiss.) Holub, Arctopoa reventa Prob., Bromopsis bargusinensis (Drobow) Tzvelev, Deschampsia bybridogena Tzvelev, Koeleria sibirensis (Domin) Tzvelev, Puccinellia bultenii Swallen. Аیя Bromopsis flexиosa и Echinochloa caudata выявлены новые (не известные ранее) значения чисел хромосом. Впервые исследованы виды в ряде регионов России: в Сибири - Cinna latifolia, Digitaria ischaemum и Echinochloa caudata, a Achnatherum confusum - впервые Амя ЗапаАной Сибири, Deschampsia susumanica и Eragrostis minor - впервые Аля Аальнего Востока, Avenella flexиosa - на Курильских островах, Agrostis scabra, Bromopsis ciliata, Elymus novae-angliae, Eragrostis multicaulis, Hordeum brachyantherum, H. jubatum, Ochlopoa annua, Poа angustifolia и P. trivialis впервые исследованы на п-ове Камчатка, Bromopsis flexиosa - впервые в Хабаровском крае, Achnatherum splendens, Elymus peschkovae, Melica nutans и Schizachne callosa - впервые в Иркутской обл., Cleistogenes squarrosa, Digitaria ischaemum и Hordeum jubatum - в Республике Бурятия, Arundinella anomala - в Забайкальском крае, Poa attenuata - в Республике Саха (Якутия).

КАючевые скова: числа хромосом, сосудистые растения, злаки, Pоасеае, флора, Россия
Here we present further results of chromosome number (CN) study of 37 Poaceae species from Russia, mainly from East Siberia and the Russian Far East, as well as from West Siberia and Crimea (Fig. 1). This contribution continue the previous publication (Probatova et al. 2015). These data will be added to the book under preparation "Poaceae of Russia" by Tzvelev \& Probatova. Chromosome countings in some species were made by E.G. Rudyka, on squashed preparations of root tips fixed with Carnoy's solution. We also included here some previously not published $\mathrm{CN}$ countings of A.P. Sokolovskaya (indicated by AS). The root tips were taken from living plants, or from seedlings obtained through herbarium specimens, which were collected in the field. Preparations were stained with iron hematoxylin. Voucher specimens are preserved in the Herbarium VLA, Vladivostok (some - in LE, TK and IRK). First $\mathrm{CN}$ data are indicated by asterisk $(*)$. The number of the dot on the map follows the special number of voucher specimen. Brief information on the affinity and distribution of the species studied is given. 


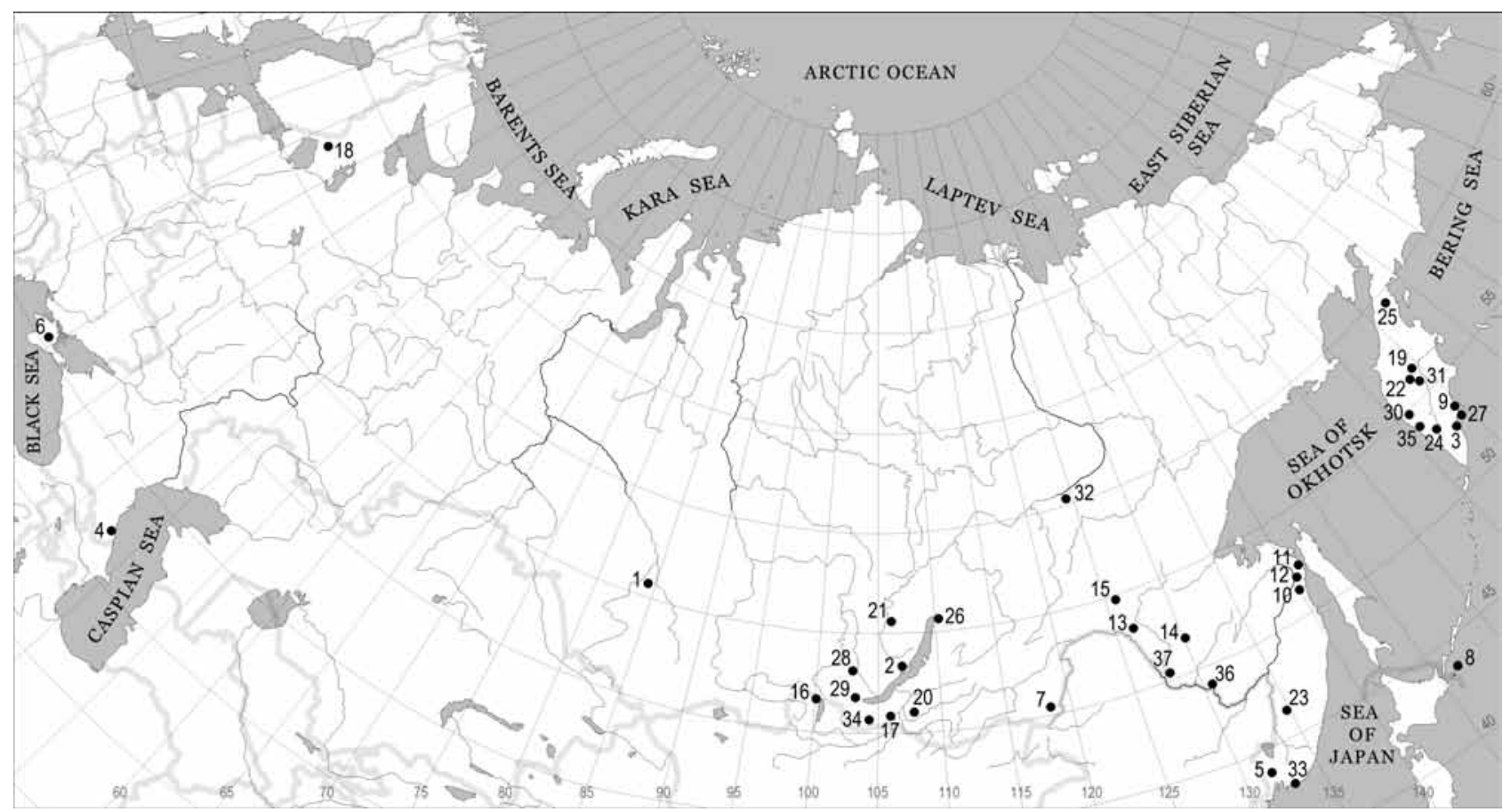

Figure 1 Study area. Dots with numbers from 1 to 37 are the sampling plot locations (according to numbering in the text)

\section{Achnatherum confusum (Litv.) Tzvelev., 2n $=24$}

Russia, West Siberia, Tomskaya Oblast', near Tomsk city, the Malaya Kirghizka River basin, open south slope, 23 Aug 2013, coll. A.L. Ebel 12737: 1 (TK). CN was obtained first for West Siberia. This species, described from Altai, is distributed mainly in Siberia; in the Russian Far East (RFE) it occurs in central Kamchatka (the Bystraya Kozyrevskaya River basin), common in Amurskaya Oblast', but rare - in Primorskii Krai and Sakhalin. The populations of $A$. confusum in Kamchatka are obviously relict, the same can be true in Sakhalin and Primorskii Krai. In Russia the CN of $A$. confusum was studied in Sakha (Yakutia) Republic, Zabaikal'skii Krai and Amurskaya Oblast' (the references will be done in the book mentioned above). The CN $2 \mathrm{n}=24$ is constant. $2 \mathrm{n}=2 \mathrm{x}(\mathrm{x}=12)$.

Achnatherum splendens (Trin.) Nevski, 2n = 48

Russia, East Siberia, Irkutskaya Oblast', Ol'khonskii Raion, the Baikal Lake, Ol'khon Island, sandy-stony riverside to the ferry quay, 15 Aug 2014, coll. D.A. Krivenko 12841: 2 (VLA, IRK). A. splendens was studied first in Irkutskaya Oblast'. This species is distributed from the south of Volga region through South Siberia, to Zabaikal'e, but mostly in Central Asia. Described from Zabaikal'e. Steppes and semideserts, solonetzic meadows and sands, stony slopes and pebbles up to the higher mountain belt. For $A$. splendens $2 \mathrm{n}=48$ is the first reliable $\mathrm{CN}$ count from Russia, and it agrees with data from Kazakhstan and Kyrgyzstan (Probatova $\&$ Seledets 2008). $2 \mathrm{n}=4 \mathrm{x}$.

\section{Agrostis scabra Willd., 2n = 42 (AS)}

Russia, the Russian Far East, Kamchatskii Krai, Kamchatka Peninsula, Petropavlovsk-Kamchatskii city, Nikol'skaya Hill, Betula ermanii forest, eroded plots on the slope, 19 Sep 1970, coll. N.S. Probatova \& V.P. Seledets 3104: 3 (VLA). North Pacific. Riverside sands and pebbles, moist erosional plots, roadsides. Its $\mathrm{CN}$ was studied many times in the RFE, from Chukotka to Primorskii Krai: the hexaploid CN 2n $=42$ is constant. In Kamchatka Peninsula the $\mathrm{CN}$ for $A$. scabra is revealed first. $2 \mathrm{n}=6 \mathrm{x}$.

*Anisantha haussknechtii (Boiss.) Holub, 2n = 28 (AS)

Russia, Caucasus, Republic of Daghestan, outskirts of Derbent city, the spur of Dzhalganskii mountain ridge, near the western wall of Naryn-Kala fortress, on the slope of a canyon, Artemisia pasture, 14 Jul 1975, coll. N.S. Probatova \& V.P. Seledets 4288: 4 (VLA). Earlier the CN of this plant was published under $A$. rubens var. caucasica (Hack.) Tzvelev (Sokolovskaya \& Probatova 1979). Mediterranean. Stony slopes, sands, gravels and slide-rocks of the lower mountain belt. Described from Iraq. In Russia $A$. haussknechtii occurs only in the east part of Caucasus. $2 \mathrm{n}=4 \mathrm{x}$.

\section{${ }^{*}$ Arctopoa reventa Prob., $2 \mathrm{n}=42$}

Russia, the Russian Far East, Primorskii Krai, Mikhailovskii Raion, northern outskirts of Novoshakhtinskii settlement, $15 \mathrm{~m}$ from the railway embankment of the Ozërnaya Pad' station, meadow in depression, 4 Jun 2012, coll. V.T. Lapenko 12113: 5 (VLA). Anthropophyte. A. reventa is studied unsufficiently yet; it occurs rarely, on disturbed habitats. Described from the south of Primorskii Krai. Its close relative is $A$. subfastigiata (Trin.) Prob. First $\mathrm{CN}$ count for the species. $2 \mathrm{n}=6 \mathrm{x}$. In the genus Arctopoa (Griseb.) Prob. almost all the species studied are hexaploids.

Arrhenatherum elatius (L.) P. Beauv. ex J. Presl et C. Presl, $2 \mathrm{n}=28$ (AS)

Russia, Republic of Crimea, Ai-Petrinskaya yaila, 5 Aug 1974, coll. V.V. Fedyaeva 3980: 6 (VLA). Euro-Mediterranean species, adventive in many temperate regions. Meadows, forest clearings. The tetraploid $\mathrm{CN} 2 \mathrm{n}=28$ is the most common for this species. Previously the $\mathrm{CN}$ of the species was studied in Russia in Leningradskaya Oblast' and Daghestan. 2n $=4 \mathrm{x}$. 


\section{Arundinella anomala Steud., $2 \mathrm{n}=36$}

Russia, East Siberia, Zabaikal'skii Krai, Nerchinsko-Zavodskii Raion, near Voznessenka village, $731 \mathrm{~m}$ alt., grassyforb meadow steppe, 29 Aug 2013, coll. S.G. Kazanovsky 12486: 7 (VLA, IRK). Mainly East Asia (partly Central Asia). Described from Japan. The CN of this species this time is studied at the western limits of its geographical range. Meadows, sands and pebbles, stony slopes and rocks, sometimes at the seacoast; up to the lower mountain belt. This is the first $\mathrm{CN}$ count for $A$. anomala from Zabaikal'skii Krai. The $\mathrm{CN}$ of the species is not constant: in Khabarovskii Krai and Primorskii Krai we revealed $2 \mathrm{n}=34,34-36,36$. The basic $\mathrm{CN}$ is unclear. $2 \mathrm{n}=2 \mathrm{x}, 4 \mathrm{x}$ ?

\section{Avenella flexuosa (L.) Drejer, 2n $=28$}

Russia, the Russian Far East, Sakhalinskaya Oblast', Kuril Islands, Shikotan Isl., $3 \mathrm{~km} \mathrm{SW}$ of Krabozavodskoe settlement, poorly matted loamy slope near the road, 3 Aug 2010, coll. V.Yu. Barkalov 11713: 8 (VLA). Mainly European. Described from Europe. Forest edges and glades, tundras, sandy meadows. The distribution of A. flexuosa is very peculiar: in Asiatic Russia the species occurs in the Russian Far East (disjunction in Siberia), and moreover, it is almost absent in continental part of the Russian Far East (except Kamchatka and near Magadan): the character of its distribution in the Russian Far East resembles some typical North Pacific species (e.g., Agrostis mertensii Trin.). Perhaps there exist a separate, NW Pacific race? A. flexuosa in the Kuril Islands was studied for the first time, earlier its CN have been studied in Russia from Karelia, Leningradskaya Oblast', Murmanskaya Oblast', Sakhalin and Kamchatka (as Lerchenfeldia flexuosa). 2n $=4 \mathrm{x}$.

\section{*Bromopsis bargusinensis (Drobow) Tzvelev, 2n $=28$}

Russia, East Siberia, Irkutskaya Oblast', Sliudyanskii Raion, left riverside of the Snezhnaya River, $555 \mathrm{~m}$ alt., sandy-pebbly bank of the river, 13 Jul 2014, coll. S.G. Kazanovsky 12899: 29 (VLA, IRK). East Siberian species, endemic of around the Baikal Lake. Riverside sands and pebbles, meadows, forest clearings; up to the middle mountain belt. Described from Transbaikalia. B. bargusinensis belongs to a complicate group of the genus $-B$. aggr. pumpelliana (Scribn.) Holub. We revealed the first $\mathrm{CN}$ for B. bargusinensis. $2 \mathrm{n}=4 \mathrm{x}$. However, the variable ploidy is quite possible within species of the $B$. aggr. pumpelliana.

\section{Bromopsis ciliata (L.) Holub, 2n $=14$}

Russia, the Russian Far East, Kamchatskii Krai, Kamchatka Peninsula, Yelizovskii Raion, the valley of Nalycheva River in its middle course, near Nalychevskie hot springs, the nature park "Nalychevo", along the path across the low shrubby tundra, frequent, 18 Aug 2015, coll. O.A. Chernyagina 12888: 9 (VLA). North Pacific. Light deciduous forests, meadows, forest edges and glades, among shrubs. Described from Canada. Earlier the species was commonly known as B. canadensis (Michx.) Holub. Distributed in Kamchatka, Sakhalin, the Kurils, also near Magadan and Nikolaevsk (the Lower Amur). Studied from Sakhalin and South Kurils. This is the only one diploid species of Bromopsis in the RFE. Its relative B. richardsonii (Link) Holub $(2 \mathrm{n}=28)$ does not occur in Russia. $2 \mathrm{n}=2 \mathrm{x}$.

\section{Bromopsis flexuosa (Drobow) Tzvelev, $2 \mathbf{n}=\mathbf{2 8}$ (AS)}

Russia, the Russian Far East, Khabarovskii Krai, Ul'chskii Raion, the Amur River, Schschuchii Island opposite Mariinskoe settlement, sandy steep, 24 Jun 1978, coll. N.S. Probatova \& E.G. Rudyka 5058: 10 (VLA); Russia, the Russian Far East, Khabarovskii Krai, Ul'chskii Raion, outskirts of Bogorodskoe settlement, sandy bank of the Amur River, among shrubs, 1 Jul 1981, coll. N.S. Probatova \& V.P. Seledets 5958: 11 (VLA); Russia, the Russian Far East, Khabarovskii Krai, Ul'chskii Raion, right riverside of the Amur River, $9 \mathrm{~km}$ down the stream of Bulava village, the Cape Auri, on pebbles, 24 Jun 1978, coll. N.S. Probatova \& E.G. Rudyka 5061: 12 (VLA).

$-2 \mathrm{n}=56(\mathrm{AS})$

Russia, the Russian Far East, Amurskaya Oblast', Tygdinskii Raion, Peremykinskii Post, 7 Jul 1977, coll. E.V. Boyko \& V.M. Starchenko 4846: 13 (VLA); Russia, the Russian Far East, Amurskaya Oblast', Selemdzhinskii Raion, $7 \mathrm{~km} \mathrm{~N}$ of Norsk settlement, the flood-plain of Selemdzha River, meadow, 19 Aug 1976, coll. N.S. Probatova \& V.P. Seledets 4571: 14 (VLA); Russia, the Russian Far East, Amurskaya Oblast', Dzheltulakskii Raion, near Tyndinskii settlement, left riverside of the Tynda River, on pebbles, coll. N.S. Probatova \& E.G. Rudyka 4013: 15 (VLA). The latter specimen was referred earlier to B. pumpelliana s. str. (Sokolovskaya \& Probatova 1977). The CN of B. flexuosa was studied first in Khabarovskii Krai. The species was described from Amurskaya Oblast' (the Bureja River). Forest edges and glades, light forests, sandy riversides, among shrubs; up to lower mountain belt. This species also belongs to $B$. aggr. pumpelliana (Scribn.) Holub. B. flexuosa is distributed mainly in the Amur River basin, from Baikal Siberia to Sakhalin. Polymorphous species: we revealed two cytotypes within B. flexuosa: tetraploid $(4 \mathrm{x})$ and octoploid $(8 \mathrm{x})$, and their distribution needs special attention. Basing on our data presented here and earlier, we suppose that populations with $2 \mathrm{n}=$ 28 occur mainly in the Lower Amur while those with $2 \mathrm{n}=$ 56 - in the upper part of the Amur River basin. One cannot exclude the role of North Pacific B. ciliata (L.) Holub in formation of more ancient - tetraploid populations in the Lower Amur, which is close to Sakhalin. These species are rather similar by habit. Further polyploidization $(8 \mathrm{x})$ could favour the migrations to the west - in the Upper Amur, and there few populations with $4 \mathrm{x}$ might also remain (Probatova \& Seledets 2008 - as B. pumpelliana: $2 \mathrm{n}=28$ - Amurskaya Oblast', Selemdzha River, Dagmara, Probatova N.S. \& Seledets V.P. 4455 - VLA). 2n $=4$ x, 8 x. Variable ploidy.

Cinna latifolia (Trevir.) Griseb., $2 \mathrm{n}=\mathbf{2 8}$

Russia, West Siberia, Republic of Khakassia, Shirinskii Raion, in vicinity of Efremkino village, the valley of the Belyi Ijus River, in forest, 17 Aug 2013, coll. A.L. Ebel 12732: 16 (TK). Nearly Holarctic. Described from Arctic America. Forest species. There are some $\mathrm{CN}$ reports for $C$. latifolia in Russia: from Republic of Buryatia, Khabarovskii Krai, Primorskii Krai, Sakhalin. The $\mathrm{CN}$ is constant. $2 \mathrm{n}=4 \mathrm{x}$.

Cleistogenes squarrosa (Trin.) Keng, $2 \mathrm{n}=40$

Russia, East Siberia, Republic of Buryatia, Tunkinskii Raion, near Zun-Murino settlement, Biological station of 
the Siberian Institute of Plant Physiology \& Biochemistry of Siberian Branch of RAS, the Khyr-Gorkhon River, $704 \mathrm{~m}$ alt., sandy slope, 21 Aug 2010, coll. Yu.N. Pochinchik 12912: 17 (VLA, IRK). East Europe-Asian. Sands, gravels, stony slopes and rocks, in steppes; up to the middle mountain belt. Described from Middle Asia. The CN of C. squarrosa was studied from Amurskaya Oblast' and Zabaikal'skii Krai and is studied first for Buryatia Republic. The CN 2n $=40$ is characteristic for all studied Cleistogenes species of Russian flora. 2n $=4 \mathrm{x}$

\section{*Deschampsia bybridogena Tzvelev, 2n $=26$}

Russia, European part, Republic of Karelia, Prjazhinskil Raion, $4 \mathrm{~km} \mathrm{~W}$ from Kolatsel'ga village, Picea forest with Vaccinium vitis-idaea and Ericaceae, forest edge, 27 Sep 2008, coll. N.S. Probatova \& V.P. Seledets 11205: 18 (VLA). The voucher specimen was identified by N.N. Tzvelev. $D$. bybridogena was described from Kola Peninsula. Distributed in European Arctic, North Europe, up to North Ural. Meadows, forest edges, riverside and coastal sands and gravels. Probably it is a hybrid of D. cespitosa (L.) P. Beauv. and D. glauca Hartm. (Tzvelev \& Probatova 2010). First CN count for the species. $2 \mathrm{n}=2 \mathrm{x}$. The $\mathrm{CN} 2 \mathrm{n}=26$ is the most common in very complicated genus Deschampsia.

Deschampsia susumanica Prob. et Chiapella, 2n $=26$

Russia, the Russian Far East, Kamchatskii Krai, Kamchatka Peninsula, Bystrinskii Raion, Opal'kinskie springs, at the rivulet, 3 Aug 2013, coll. V.V. Buryi 12596: 19. (VLA). D. susumanica was described in 2015 from Magadanskaya Oblast' (Susumanskii Raion). Riverside sands and pebbles, near hot springs. Distributed in Lena and Kolyma rivers basins and in Kamchatka Peninsula. Endemic. The $\mathrm{CN}$ is obtained first for D. susumanica in the Russian Far East. Before $2 \mathrm{n}=26$ was revealed in Yakutia (Tzvelev et al. 2015). $2 \mathrm{n}=2 \mathrm{x}$.

Digitaria ischaemum (Schreb.) Muhl., 2n = 36

Russia, East Siberia, Republic of Buryatia, Kjakhtinskii Raion, in vicinity of Ust'-Kjakhta settlement, the Selenga River, right riverside, $565 \mathrm{~m}$ alt., stony-uliginous bank, riverside plant community, 13 Aug 2015, coll. S.G. Kazanovsky 12896: 20 (VLA, IRK). The species is described from Germany. Europe-Caucasian species, adventive in Siberia, the Russian Far East, North America and in other temperate regions. Riverside sands and gravels, pine forests, roadsides, in settlements; up to the middle mountain belt. D. ischaemum is studied in Siberia for the first time. The CN counts were made in Russia from Volga region and Primorskii Krai. The $\mathrm{CN} 2 \mathrm{n}=36$ is constant. $2 \mathrm{n}=4 \mathrm{x}$.

\section{Echinochloa caudata Roshev., *2n = 54}

Russia, East Siberia, Republic of Buryatia, Kjakhtinskii Raion, in vicinity of Ust'-Kjakhta settlement, the Selenga River, right riverside, $565 \mathrm{~m}$ alt., stony-uliginous bank, riverside plant community, 13 Aug 2015, coll. S.G. Kazanovsky 12895: 20 (VLA, IRK). East Asian, mainly in the Amur River basin, sometimes as adventive. Rice fields, sand and pebble river banks, damp meadows, roadsides. Described from Dahuria (the Argun' River). The $\mathrm{CN}$ of E. caudata is studied in Siberia for the first time and it is a new CN for the species: in Khabarovskii Krai and Primorskii Krai we revealed for E. caudata $2 \mathrm{n}=36$ (Sokolovskaya \& Probatova 1977). Variable ploidy. 2n $=4 \mathrm{x}, 6 \mathrm{x}$.

\section{Elymus novae-angliae (Scribn.) Tzvelev, $2 \mathrm{n}=\mathbf{2 8}$}

Russia, the Russian Far East, Kamchatskii Krai, Kamchatka Peninsula, Bystrinskii Raion, NW part of the nature park "Bystrinskii", $468 \mathrm{~m}$ alt., on the roadside, 3 Aug 2014, coll. V.V. Buryi 12820: 22 (VLA). North American species. Widely introduced as forage grass and occurs not rarely in Russia as adventive or wilding on roadsides, in settlements, field edges. In Russia its CN was revealed from Novossibirskaya Oblast', Omskaya Oblast', Irkutskaya Oblast', Amurskaya Oblast', Khabarovskii Krai and Primorskii Krai. This is the first $\mathrm{CN}$ report from Kamchatka Peninsula. $2 \mathrm{n}=4 \mathrm{x}$.

\section{Elymus pendulinus (Nevski) Tzvelev, 2n $=28$}

Russia, West Siberia, Republic of Khakassia, Shirinskii Raion, in vicinity of Efremkino village, lower part of the slope to the valley of the Belyi Ijus River, in shrubs, 17 Aug 2013, coll. A.L. Ebel 12733: 16 (TK). East Asian species, distributed in the south of East Siberia and the Russian Far East. Now it is studied at the west border of its geographical area. Forest clearings and forest edges, among shrubs; up to the lower mountain belt. Described from the south of the Amur River (Soyuznoe). The CN was known from Zabaikal'skii Krai, Khabarovskii Krai and Primorskii Krai. $2 \mathrm{n}=4 \mathrm{x}$.

\section{Elymus peschkovae Tzvelev, $2 \mathrm{n}=28$}

Russia, East Siberia, Irkutskaya Oblast', KazachinskoLenskii Raion, $78 \mathrm{~km}$ from Okunajskii settlement to Zhigalovo, right riverside of the Kharakhikta River, $831 \mathrm{~m}$ alt., on the roadside, 11 Aug 2014, coll. D.A. Krivenko 12964: 21 (VLA, IRK). East Siberia - Far East. Stony slopes, rocks and pebbles; up to the middle mountain belt. Described from Yakutia. E. peschkovae is studied in Irkutskaya Oblast' for the first time; the $\mathrm{CN}$ was known from Magadanskaya Oblast' and Amurskaya Oblast'. 2n $=4 \mathrm{x}$.

\section{Eragrostis minor Host, 2n $=40$}

Russia, the Russian Far East, Khabarovskii Krai, Bikinskii Raion, Bikin town, along the railway embankment, 17 Sep 2009, coll. L.A. Antonova 12716: 23 (VLA). Mainly Euro-Mediterranean; as adventive - in Siberia, in the RFE and in many other countries. Riverside sands and gravels, in steppes, on roadsides, a weed in settlements. Described from Italy. The $\mathrm{CN}$ was obtained first for E. minor in the Russian Far East. The same CN 2n $=40$ was revealed in Russia from Krasnodarskii Krai, Daghestan, Zabaikal'skii Krai. However from Zabaikal'e also $2 \mathrm{n}=20$ and 30 were reported (see Chepinoga 2014). Variable ploidy. $2 n=? 2 x$, $4 \mathrm{x}$ and aneuploids?

\section{Eragrostis multicaulis Steud., 2n $=40$}

Russia, the Russian Far East, Kamchatskii Krai, Kamchatka Peninsula, Ust'-Bol'sheretskii Raion, flood-lands of the Bannaya River, on thermal field, 17 Aug 2014, coll. O.A. Chernyagina \& L. Shtreker 12791: 24 (VLA). East Asia. In the south of RFE, alien in some regions of European Russia. Anthropophyte. Riverside sands and gravels, field edges, roadsides, as a weed in settlements. Described from Japan. This is the second $\mathrm{CN}$ report for the species; 
the first was from Primorskii Krai. E. multicaulis is studied from Kamchatka Peninsula for the first time. $2 n=4 x$.

\section{Eragrostis pilosa (L.) P. Beauv., 2n $=20$}

Russia, the Russian Far East, Amurskaya Oblast', Blagoveshchensk city, on roadside, 12 Sep 2001, coll. E. Aistova 11802: 37 (VLA); Russia, the Russian Far East, Amurskaya Oblast', Arkharinskii Raion, Leninskoe settlement, the grass-plot near the office of collective farm "Fakel", 25 Jul 2005, coll. T.N. Tolmacheva 11801: 36 (VLA). Eurasian. Riversides, gravels, on roadsides and in settlements. Anthropophyte. Described from Italia. The most common species of Eragrostis in the Russian Far East. The CN 2n = 20 is rare for E. pilosa, however it was already revealed from Primorskii Krai (Probatova et al. 2009), while from Zabaikal'skii Krai 2n $=40$ is known (Chepinoga et al. 2009; Chepinoga \& Gnutikov 2014). The CN 2n = 20 was reported either from Slovakia (Murin et al. 1999); also there are some aneuploid reports for the species. Variable ploidy. $2 \mathrm{n}=2 \mathrm{x}$, $4 \mathrm{x}$ and aneuploids.

\section{Festuca extremiorientalis Ohwi, 2n $=28$}

Russia, West Siberia, Republic of Khakassia, Shirinskii Raion, in vicinity of Efremkino village, the valley of Belyi Iyus River, in forest, 17 Aug 2013, coll. A.L. Ebel 12725: 16 (TK). East Asia. Occurs in South Siberia, South Far East. In forests. Described from Korea. The CN is constant, it was already known in Russia from Khabarovskii Krai, Primorskii Krai, South Kuriles. 2n $=4 x$.

\section{Glyceria orientalis Kom., $2 \mathrm{n}=20$}

Russia, the Russian Far East, Kamchatskii Krai, Kamchatka Peninsula, Karaginskii Raion, Drankinskie hot springs, between Severnaya and Yuzhnaya groups, lower part of the slope, at the cold rivulet, 2 Sep 2015, coll. O.A. Chernyagina 12882: 25 (VLA); Kamchatka Peninsula, Petropavlovsk-Kamchatskii city, S slope of Petrovskaya Hill, Gagarina Street, at the rivulet, abundant, 14 Sep 2014, coll. O.A. Chernyagina 12875: 3 (VLA). Endemic of Kamchatka. Flood-plain meadows, Salix communities, along the rivulets. Described from Kamchatka (the Paratunka River basin). The species is obviously hybridogenous: $G$. alnasteretum Kom. $\times$ G. lithuanica (Gorski) Gorski. Its CN was revealed first by A.P. Sokolovskaya (1963). $2 \mathrm{n}=2 \mathrm{x}$.

\section{Hordeum jubatum L., 2n = 28}

Russia, East Siberia, Republic of Buryatia, Severo-Baikal'skii Raion, in vicinity of Nizhneangarsk town, the Baikal Lake, Yarki Island, $521 \mathrm{~m}$ alt., on sands, 8 Aug 2014, coll. D.A. Krivenko 12842: 26 (VLA, IRK); Russia, the Russian Far East, Kamchatskii Krai, Kamchatka Peninsula, Bystrinskii Raion, Opal'kinskii Spring, $736 \mathrm{~m}$ alt., at the rivulet, 3 Aug 2013, coll. V.V. Buryi 12802: 19 (VLA). North America; actively expanding in Europe, as well as in Middle, Central and East Asia, naturalized in many regions and in all the Russian Far East. Disturbed meadows, gravels, roadsides, in settlements. Described from Canada. For H. jubatum this is the first $\mathrm{CN}$ report from Kamchatka Peninsula as well as from Buryatia Republic. CN counts in Russia were from Irkutskaya Oblast', Yakutia, Magadanskaya Oblast', Amurskaya Oblast', Primorskii Krai. 2n $=4 \mathrm{x}$.

\section{Hordeum brachyantherum Nevski, $2 \mathrm{n}=28$}

Russia, the Russian Far East, Kamchatskii Krai, Kamchatka Peninsula, Avachinskaya Bay, the mouth of the Paratunka River, along the coast, in tidal zone, 23 Sep 2014, coll. O.A. Chernyagina 12790: 27 (VLA). North Pacific (Kamchatka, the Kurils, Commander Isls). Described from Aleutian (Atka Isl.) and Commander (Bering) islands, from Alaska to California and Oregon. Meadows and pebbles, roadsides. Anthropophyte. The $\mathrm{CN}$ was earlier revealed from Bering Isl. (Probatova \& Sokolovskaya 1982). For $H$. brachyantherum this is the first $\mathrm{CN}$ report from Kamchatka Peninsula. $2 \mathrm{n}=4 \mathrm{x}$.

\section{*Koeleria sibirensis (Domin) Tzvelev, 2n $=28$}

Russia, East Siberia, Irkutskaya Oblast', Ust'-Ordynskii Buryatskii Okrug, Alarskii Raion, near Aljaty settlement, the Aljaty Lake, along the lakeside, 4 Jul 2011, coll. A.A. Gnutikov 12288: 28 (VLA). First CN data for the species. Earlier this specimen was erroneously referred to K. cristata (L.) Pers. (Probatova et al. 2013). The species is endemic, it was described from Lena River and it is distributed around the Baikal Lake and in South Yakutia. Occurs on riverside and lakeside sands and pebbles, meadows and forest clearings. $2 \mathrm{n}=4 \mathrm{x}$.

\section{Melica altissima L., 2n $=18$}

Russia, West Siberia, Republic of Khakassia, Shirinskii Raion, in vicinity of Efremkino village, right riverside of the Belyi Iyus River, rocky massif Togyz-Az, stony sliderocks, 9 Aug 2013, coll. A.L. Ebel 12735: 16 (TK). Geographical area: East Europe - Siberia - Central Asia. Light forests, forest edges and glades, stony slopes and rocks, among shrubs; up to the middle mountain belt. In Russia it occurs in European part, Caucasus, Siberia. Described from Siberia. The CN was studied in Russia in Stavropol'skii Krai, Permskii Krai, Altai Republic. 2n $=2 \mathrm{x}$.

\section{Melica nutans L., $2 \mathrm{n}=18$}

Russia, East Siberia, Irkutskaya Oblast', Sliudyanskii Raion, left riverside of the Snezhnaya River, $569 \mathrm{~m}$ alt., Pinus sibirica forest with Abies, Populus, Waldsteinia and forbgrass layer, 13 Jul 2014, coll. S.G. Kazanovsky 12901: 29 (VLA, IRK). Eurasian. In forests, among shrubs; up to the upper mountain belt. In Russia M. nutans was studied earlier in Permskii Krai and Buryatia Republic, now it is studied first in Irkutskaya Oblast'. Isolated populations from Kamchatka and Sakhalin may belong to a separate species. $2 \mathrm{n}$ $=2 \mathrm{x}$.

Ochlopoa annua (L.) H. Scholz, $2 \mathrm{n}=\mathbf{2 8}$

Russia, the Russian Far East, Kamchatskii Krai, Kamchatka Peninsula, Sobolevskii Raion, in vicinity of Sobolevo, Ustjevoe settlement, 12 Aug 2014, coll. R.N. Bukhalova \& Yu.N. Gerassimov 12793: 35 (VLA). Cosmopolite. Anthropophyte. Roadsides, disturbed plots, riversides, as a weed in settlements; to the upper mountain belt. In the Russian Far East - everywhere, except the Arctic. Described from Europe. In Russia the $\mathrm{CN}$ was studied (under the name Poa annua L.) from Permskii Krai, Irkutskaya Oblast', Amurskaya Oblast', Khabarovskii Krai, Primorskii Krai, Sakhalin, the Kurils (Paramushir, Onekotan). This is the first $\mathrm{CN}$ report from Kamchatka Peninsula. 2n $=4 x$. 


\section{Poa angustifolia L., 2n $=\mathbf{5 6}$}

Russia, the Russian Far East, Kamchatskii Krai, Kamchatka Peninsula, Bystrinskii Raion, outskirts of Esso settlement, $497 \mathrm{~m}$ alt., forb meadow, 11 Jul 2014, coll. V.V. Buryi 12792: 31 (VLA). Eurasian, introduced to North America and elsewhere in temperate regions. Dry meadows, steppes, riverside and coastal sands and pebbles, roadsides. In all the RFE (but alien in the north, in Sakhalin and in the Kurils). Described from Europe. In Russia the $\mathrm{CN}$ was studied from Leningradskaya Oblast', Saratovskaya Oblast', Irkutskaya Oblast', Zabaikal'skii Krai, North Koryakia, Primorskii Krai, Sakhalin $(2 \mathrm{n}=56,63-64$, c. 70, 70-72), and this is the first $\mathrm{CN}$ report from Kamchatka Peninsula. Variable ploidy. $2 \mathrm{n}=8 \mathrm{x}, 9 \mathrm{x}, 10 \mathrm{x}$ and aneuploids.

\section{Poa attenuata Trin., $2 \mathrm{n}=28$}

Russia, East Siberia, Sakha-Yakutia Republic, central part, the Vilui River basin, near Kyssyl-Syr settlement, Makhatta tukulan, the flood-plain of the Vilui River, Salix forest on sandy beach, 13 Jul 2015, coll. I.A. Galanina 12873: 32 (VLA). Siberian species. Stony slopes, pebbles, highland steppes; in the middle and upper mountain belts. Described from Altai. The CN was studied in Russia from Altai Republic, Irkutskaya Oblast', Buryatia Republic, Zabaikal'skii Krai. This is the first $\mathrm{CN}$ count from Yakutia. The tetraploid CN $2 \mathrm{n}=28$ is constant in P. attenuata. $2 \mathrm{n}=4 \mathrm{x}$.

\section{Poa trivialis L., $2 \mathrm{n}=14$}

Russia, the Russian Far East, Kamchatskii Krai, Kamchatka Peninsula, Sobolevskii Raion, the Bol'shaya Vorovskaya River basin, in vicinity of Sobolevo settlement, swampy flooding riverside, 12 Aug 2014, coll. R.N. Bukhalova \& Yu.N. Gerassimov 12793: 30 (VLA). Euro-Siberian species, alien elsewhere in the world in all continents. Adventive in the Russian Far East. Moist meadows, riversides, roadsides. Described from Europe. CN counts in Russia - from Leningradskaya Oblast', Karelia, Primorskii Krai, Sakhalin, South Kurils (Shikotan Isl.). For P. trivialis this is the first $\mathrm{CN}$ report from Kamchatka. $2 \mathrm{n}=2 \mathrm{x}$.

\section{*Puccinellia bultenii Swallen, 2n $=42$}

Russia, the Russian Far East, Primorskii Krai, Nakhodka city, southern microdistrict, Sportivnaya Street, roadside, 20 Aug 2013, coll. S.V. Prokopenko 12551: 33 (VLA). First CN count for the species. This is the only one reliable site of this North American (N Pacific?) species in Russia; moreover, it has already been collected from Nakhodka Bay in 1913 (Nakhodka, meadow along the seacoast, on sands, 18 VI 1913, coll. A. Bulavkina 310 - LE). It was also reported from the mouth of Penzhina River. Described from Alaska. Anthropophyte. $2 \mathrm{n}=6 \mathrm{x}$.

\section{Schedonorus giganteus (L.) Soreng et Terrell, $2 n=42$}

Russia, West Siberia, Tomskaya Oblast', in vicinity of Tomsk city, left riverside of the Malaya Kirghizka River (the Tom' River basin), valley of the rivulet, birch forest (Betula pubescens), 20 Aug 2013, coll. A.L. Ebel 12607: 1 (TK). Europe, West Siberia, South-West and Middle Asia, introduced to North America. Forest species. In Russia its CN was studied from Caucasus (Krasnodarskii Krai, Chechenskaya Republic, Kabardino-Balkaria Republic), Permskii
Krai, Novosibirskaya Oblast, Krasnoyarskii Krai (West Sayan Mts.). The most common $\mathrm{CN}$ for $S$. gigantea is $2 \mathrm{n}$ $=42$, however $2 \mathrm{n}=28$ was revealed three times. Variable ploidy. $2 \mathrm{n}=4 \mathrm{x}, 6 \mathrm{x}$.

Schizachne callosa (Turcz. ex Griseb.) Ohwi, $2 \mathbf{n}=\mathbf{2 0}$

Russia, East Siberia, Irkutskaya Oblast', Sliudyanskii Raion, lower course of the Sliudyanka River, right riverside, $570 \mathrm{~m}$ alt., Populus suaveolens forest with forb layer, 7 Aug 2015, coll. S.G. Kazanovsky 12946: 34 (VLA, IRK). East Europe - Siberia - Central and East Asia. Forest species; up to the middle mountain belt. Distributed in the most part of the Russian Far East, except Kamchatka and northwards. Described from Baikal Lake. The $\mathrm{CN}$ is constant, it was studied in Russia from Altai Republic, Zabaikal'skii Krai, Khabarovskii Krai, Primorskii Krai. S. callosa was studied first in Irkutskaya Oblast'. $2 \mathrm{n}=2 \mathrm{x}$.

\section{CONCLUSION}

The 37 species from 24 genera presented here demonstrate the diversity of CNs: different ploidy levels, a series of basic $\mathrm{CN}$ numbers $(\mathrm{x}=7,9,10,12,13,17)$. The tetraploids prevail (18 species), but 11 species are diploids. There are species with variable ploidy in Bromopsis, Echinochloa, Schedonorus, Poa and this phenomenon indicates progressive species. The tetraploid CNs $(2 \mathrm{n}=4 \mathrm{x})$ prove the optimal ploidy level for species. The hexaploid CN $(2 \mathrm{n}=$ $6 \mathrm{x})$ indicates the hybrid origin of the taxa. 6 species were studied caryologically for the first time. For 2 species the new $\mathrm{CN}$ data were obtained.

\section{ACKNOWLEDGEMENTS}

The study was supported by Russian Foundation for Basic Research (RFBR): grants 04-04-49750, 07-04-00610, 11-04-00240, to N.S. Probatova. The authors are grateful to E.G. Rudyka for chromosome countings in several species, to N.N. Tzvelev - for his help in some species identifications, to plant collectors: L.A. Antonova, V.Yu. Barkalov, V.V. Buryi, A.L. Ebel, I.A. Galanina, S.G. Kazanovsky, D.A. Krivenko, S.V. Prokopenko - for providing valuable plant material for our study.

\section{I T E R A T U R E CITE D}

Chepinoga, V.V. 2014. Chromosome numbers of plant species from Baikal Siberia. Nauka, Novosibirsk, 419 pp. (in Russian). [Чепинога В.В. 2014. Хромосомные числа растений флоры Байкальской Сибири. Новосибирск: Наука. 419 c.].

Chepinoga, V.V. \& A.A. Gnutikov 2014. Chromosome numbers of some vascular plant species from the south of the Baikal Siberia. Botanica Pacifica 3(1):53-60.

Chepinoga, V.V., A.A. Gnutikov, I.V. Enushchenko \& S.A. Rosbakh 2009. IAPT/IOPB chromosome data 8 (K. Marhold, ed.). Taxon 58(4):1281-1282, E 1-3.

Murin, A., Z. Svobodová, J. Májovský \& V. Feráková 1999. Chromosome numbers of some species of the Slovak flora. Thaiszia 9 (1):31-40.

Probatova, N.S., S.G. Kazanovsky, E.G. Rudyka, A.A. Gnutikov \& A.V. Verkhozina 2013. IAPT/IOPB chromosome data 15 (K. Marhold, ed.). Taxon 62(5):1080-1081, E 23-26. 
Probatova, N.S., Z.V. Kozhevnikova, E.G. Rudyka, A.V. Shatokhina, A.E. Kozhevnikov, V.Yu. Barkalov \& V.P. Seledets 2009. Chromosome numbers in species of the flora of the Far East and East Siberia. Botanicheskii Zhurnal 94(5): 764-780 (in Russian). [Пробатова Н.С., Кожевникова 3.В., Рудыка Э.Г., Шатохина А.В., Кожевников А.Е., Баркалов В.Ю., Селедец В.П. 2009. Числа хромосом видов флоры Аальнего Востока и Восточной Сибири // Ботанический журнам. Т. 94, № 5. С. 764 780].

Probatova, N.S. \& V.P. Seledets 2008. IAPT / IOPB chromosome data 5 (K. Marhold, ed.). Taxon 57(2):555-558, E 7-16.

Probatova, N.S., V.P. Seledets \& V.Yu. Barkalov 2015. Chromosome numbers in some species of Poaceae from Russia. Botanica Pacifica 4(1):59-67.

Probatova, N.S. \& A.P. Sokolovskaya 1982. Synopsis of chromosome numbers in Poaceae of the Soviet Far East. 1. Tribes Oryzeae, Brachypodieae,Triticeae. Botanicheskii Zhurnal 67(1):62-70 (in Russian). [Пробатова H.C., Соколовская А.П. 1982. Конспект хромосомных чисел Роасеае советского Аальнего Востока. 1. Трибы Oryzeae, Brachypodieae, Triticeae // Ботанический журнал. Т. 67, № 1. С. 62-70.

Sokolovskaya, A.P. 1963. Geographical distribution of polyploid plant species (study on the flora of Kamchatka Peninsula). Vestnik Leningradskogo Universiteta, Ser. biol. 3
(15):38-52 (in Russian). [Соколовская А.П. 1963. Географическое распространение полиплоидных видов растений (Исследование флоры полуострова Камчатка) // Вестник Аенингр. унив. Сер. биол. Т. 3, вып. 15. С. 38-52].

Sokolovskaya, A.P. \& N.S. Probatova 1977. Karyological study of Poaceae in south part of the Soviet Far East. Botanicheskii Zhurnal 62(8):1143-1153 (in Russian). [Сокомовская А.П., Пробатова Н.С. 1977. Кариологическое исследование злаков (Роасеае) южной части советского АаАьнего Востока // Ботанический журнац. T. 62, № 8. C. 1143-1153].

Sokolovskaya, A.P. \& N.S. Probatova 1979. Chromosome numbers of some grasses (Poaceae) of the flora of the USSR. III. Botanicheskii Zhurnal 64(9):1245-1258 (in Russian). [Соколовская А.П., Пробатова Н.С. 1979. Хромосомные числа некоторых злаков (Роасеае) фморы СССР. III // Ботанический журнал. Т. 64, № 9. C. 1245-1258].

Tzvelev, N.N. \& N.S. Probatova 2010. New taxa of Poaceae from Russia. Botanicheskii Zhurnal 95(6):857-869 (in Russian). [Цвелёв Н.Н., Пробатова Н.С. 2010. Новые таксоны зАаков (Роасеае) России // Ботанический журнац. Т. 95, № 6. С. 857-869].

Tzvelev, N.N., Probatova N.S. \& J. Chiapella 2015. New taxa of Deschampsia P. Beauv. (Poaceae) from Russia. Botanica Pacifica 4(1):53-58. 